\title{
Synthesis of Heterobimetallic Allene Complexes
}

\author{
Iuan-Yuan Wu, Tian-Wen Tseng, Chun-Ting Chen, Ming-Chu Cheng, Ying-Chih Lin," and Yu Wang
}

Department of Chemistry, National Taiwan University, Taipei, Taiwan 10764, Republic of China

Received October 15, 1992

The first dinuclear complex containing a four-electron $\mu-\eta^{2}, \eta^{2}-$ allene ligand was synthesized from the reaction of allene with $\left[\mathrm{Cp}(\mathrm{CO})_{2} \mathrm{Mo}\right]_{2}\left(\mathrm{Cp}=\eta^{5}-\mathrm{C}_{5} \mathrm{H}_{5}\right)$ and was reported in 1977.1 Thereafter, a number of complexes of this type were prepared, ${ }^{2}$ notably by photolysis of dinuclear complexes with a bridging cyclopropylidene ligand. $2 b, c$ Several dinuclear and trinuclear metal complexes containing allenyl ligands in various bonding modes have been prepared by initially using a propargyl ligand as a template. ${ }^{3}$ Despite these and other reports, ${ }^{4}$ methods that lead to formation of a heterodinuclar $\mu-\eta^{2}, \eta^{2}$-allene complex are still lacking. ${ }^{5}$ In exploring the chemistry of a tungsten $\beta$-(chlorocarbonyl)allylic complex $\mathrm{Cp}(\mathrm{CO})_{2} \mathrm{~W}\left(\eta^{3}-\mathrm{CH}_{2} \mathrm{C}(\mathrm{COCl}) \mathrm{CH}_{2}\right)$ (1a) ${ }^{6}$ we prepared several dinuclear complexes by replacing the $\mathrm{Cl}$ atom with another metal group and found photolysis of such complexes provided a systematic a pproach to the dinuclear $\mu-\eta^{2}, \eta^{2}$ allene complexes. Herein, we report several complexes synthesized via this approach and their characterization.

The reaction of $\mathrm{Cp}(\mathrm{CO})_{2} \mathrm{~W}\left(\eta^{3}-\mathrm{CH}_{2} \mathrm{C}(\mathrm{COCl}) \mathrm{CH}_{2}\right)(1 \mathrm{a})^{6}$ with $\mathrm{Cp}(\mathrm{CO})_{3} \mathrm{~W}$ - in THF resulted in the formation of a homonuclear complex $\mathrm{Cp}(\mathrm{CO})_{2} \mathrm{~W}\left[\mu-\eta^{3}, \eta^{1}-\mathrm{CH}_{2} \mathrm{C}(\mathrm{CO}) \mathrm{CH}_{2}\right] \mathrm{W}(\mathrm{CO})_{3} \mathrm{Cp}$ (2a). Heteronuclear analogues $\mathrm{Cp}(\mathrm{CO})_{2} \mathrm{M}\left(\mu-\eta^{3}, \eta^{1}-\mathrm{CH}_{2} \mathrm{C}(\mathrm{CO}) \mathrm{CH}_{2}\right) \mathrm{M}^{\prime}$ (2b, $\mathbf{M}=\mathrm{Mo}, \mathrm{M}^{\prime}=\mathrm{W}(\mathrm{CO})_{3} \mathrm{Cp} ; \mathbf{2 c}, \mathbf{M}=\mathrm{W}, \mathrm{M}^{\prime}=\mathrm{Fe}(\mathrm{CO})_{2} \mathrm{Cp}$; 2d, $M=W, M^{\prime}=\operatorname{Re}(C O)_{5}$ ) were prepared similarly. However, attempts to prepare similar complexes using the $\mathrm{Cp}(\mathrm{CO})_{3} \mathrm{Mo}^{-}$ anion were unsuccessful. We believe that metal anions with weak nucleophilicity ${ }^{7}$ may not be applicable for the preparation of 2 employing this synthetic strategy. On the basis of the EAN rule, the two metal centers in 2 bridged by a $\mu-\eta^{3}, \eta^{1}-\beta$-carbonylallylic ligand should have no $\mathbf{M}-\mathbf{M}$ bond. Complexes 2 were characterized through a combination of microanalytical data and IR, ${ }^{1} \mathrm{H}$ NMR, and ${ }^{13} \mathrm{C}$ NMR spectroscopy. ${ }^{8}$ For example, in the ${ }^{1} \mathrm{H}$ NMR spectrum of $2 \mathrm{a}$ at room temperature, the two inequivalent $C p$ groups displayed a sharp resonance and a broad resonance and the allylic syn and anti protons appeared as two broad resonances at $\delta 2.76$ and 1.38, respectively. These broad resonances are due to the fluxional behavior of the endo and exo configurations of the allylic group. At $240 \mathrm{~K}$, the two broad resonances at $\delta 2.76$ and 1.38 of $2 \mathrm{a}$ were resolved into two sets of allylic protons at $\delta 2.78,1.16$ and $2.68,1.58,{ }^{8}$ assignable to those of the endo and exo isomers, respectively.

Photolysis of complexes $2 a-c$ with UV irradiation in benzene resulted in the loss of two $\mathrm{CO}$ ligands and afforded the dinuclear

(1) Chisholm, M. H.; Rankel, L. A.; Bailey, W. I.; Cotton, F. A.; Murillo, C. A. J. Am. Chem. Soc. 1977, 99, 1261 .

(2) (a) Lewis, L. N.; Huffmann, J. C.; Caulton, K. G. J. Am. Chem. Soc. 1980, 102, 403. (b) Casey, C. P.; Austin, E. A. Organometallics 1986 5, 584. (c) Casey, C. P.; Austin, E. A. J. Am. Chem. Soc. 1988, 110, 7106 . (d) Hoel, E. L.; Ansell, G. B.; Leta, S. Organometallics 1986, 5,585 .

(3) (a) Wojcicki, A.; Shuchart, C. E. Coord. Chem. Rev. 1990, 105, 35. (b) Young, G. H.; Raphael, M. V.; Wojcicki, A.; Calligaris, M.; Nardin, G.; Bresciani-Pahor, N. Organometallics 1991, 10, 1934-1945.

(4) Jones, M. D.; Kemmitt, R. D. W. Adv. Organomet. Chem. 1987, 27 279.

(5) A Ni-W complex previously thought to have a $\mu-\eta^{2}, \eta^{2}$-allene ligand was found to have a $\mu-\eta^{3}, \eta^{1}$ structure: (a) Chetcuti, M. J.; Fanwick, P. E.; McDonald, S. R.; Rath, N. N. Organometallics 1991, 10, 1551. (b) Chetcuti, M. J.; McDonald, S. R.; Rath, N. N. Organometallics 1989 , $8,2077$.

(6) Tseng, T. W.; Wu, I. Y.; Lin, Y. C.; Chen, C. T.; Chen, M. C.; Tsai, Y. J.; Chen, M. C.: Wang, Y. Organometallics 1991, 10, 43.

(7) King, R. B. Acc. Chem. Res. 1970, 3, 417.

(8) Preparations and spectroscopic data of these complexes are given in the supplementary material. allene complexes $\mathrm{Cp}(\mathrm{CO})_{2} \mathrm{M}\left(\mu-\eta^{2}, \eta^{2}-\mathrm{CH}_{2}=\mathrm{C}=\mathrm{CH}_{2}\right) \mathrm{M}^{\prime \prime}$ (4a, $\mathrm{M}=\mathrm{W}, \mathrm{M}^{\prime \prime}=\mathrm{W}(\mathrm{CO})_{2} \mathrm{Cp} ; 4 \mathrm{~b}, \mathrm{M}=\mathrm{Mo}, \mathrm{M}^{\prime \prime}=\mathrm{W}(\mathrm{CO})_{2} \mathrm{Cp} ; 4 \mathrm{c}$, $\mathrm{M}=\mathrm{W}, \mathrm{M}^{\prime \prime}=\mathrm{Fe}(\mathrm{CO}) \mathrm{Cp}$ ); see Scheme I. Complexes 4 were characterized by spectroscopic methods. In addition, the molecular structure of $4 \mathrm{c}$ was determined by an X-ray diffraction analysis. ${ }^{9}$ In each unit cell, there are two independent molecules which are an enantiomeric pair and differ only slightly in their bond lengths and angles. Figure 1 shows one of the molecules. As expected, the $\mathrm{C}_{3}$ unit is nonlinear with a $\mathrm{C}-\mathrm{C}-\mathrm{C}$ bond angle of $140(4)^{\circ}$. The three-carbon allene unit sits above the $\mathrm{W}-\mathrm{Fe}$ axis in a criss-cross arrangement. This geometry allows interaction of one $\pi$-bond of the allene with the $W$ center and of the second $\pi$-bond of the allene with the Fe center. With such a structure, the heteronuclear system should display two sets of inequivalent geminal protons, i.e. proximal and distal with respect to the $\mathbf{M}-\mathbf{M}^{\prime}$ bond. Indeed, in the ${ }^{1} \mathrm{H}$ NMR spectra of heteronuclear allene complexes, four allene protons displayed four multiplet resonances $(\delta 4.50,3.02,2.66,2.40$ for $4 c$ and $\delta 4.22,3.69,2.67,2.45$ for 4b). In contrast, in the homonuclear system,' there is a $C_{2}$ axis passing through the center carbon of the allene ligand and the midpoint of the $\mathrm{M}-\mathrm{M}$ vector. Therefore, in the ${ }^{1} \mathrm{H}$ NMR spectrum of $4 a$, a deceptively simple triplet pattern for the methylene protons was observed.

In the photolytic decarbonylation reactions of $\mathbf{2 a}$ and $\mathbf{2 b}$, an intermediate formulated as $\mathrm{Cp}(\mathrm{CO})_{2} \mathrm{M}\left(\mu-\eta^{3}, \eta^{1}-\mathrm{CH}_{2} \mathrm{CCH}_{2}\right)$ $\mathbf{W}(\mathrm{CO}){ }_{3} \mathrm{Cp}(3 \mathbf{a}, \mathbf{M}=\mathrm{W} ; \mathbf{3 b}, \mathbf{M}=\mathrm{Mo})$ was observed. Presumably, the two metal centers in 3 are bridged by a $\eta^{3}, \eta^{1}$-allylic ligand as shown in the Scheme $1 .{ }^{10}$ Complexes $3 a$ and $3 b$ were observed but not isolated. ${ }^{8}$ Interestingly, for thenium complex $2 \mathrm{~d}$, only one decarbonylation was attained and the complex $\mathrm{Cp}(\mathrm{CO})_{2} \mathrm{~W}\left(\mu-\eta^{3}, \eta^{1}-\mathrm{CH}_{2} \mathrm{CCH}_{2}\right) \operatorname{Re}(\mathrm{CO})_{5}$ (3d) was isolated in $45 \%$ yield. In the ${ }^{1} \mathrm{H}$ NMR spectrum of $3 \mathrm{~d}$, the resonances of the allylic protons at $\delta 3.09,1.67$ are typical for syn/anti resonances of an allylic system. The mass spectrum of $\mathbf{3 d}$ displayed parent peaks as well as fragmentations due to loss of $\mathrm{CO} .^{7} \mathrm{~W}-\mathrm{Re}$ metalmetal bonds have been observed in several complexes. ${ }^{11}$ Reasons for no further decarbonylation of $\mathbf{3 d}$ are not clear.

(9) Yellow crystals of $4 c$ were grown by slow diffusion of $n$-hexane into a dichloromethane solution of $4 \mathbf{c}$ at $4^{\circ} \mathrm{C}$. Crystal data: space group $P 2,2,2, a=7.606(2) \AA, b=12.333(6) \AA, c=31.072(7) \AA, Z=4$. $\mathrm{X}$-ray data were collected at room temperature on an Enraf-Nonius CAD4 diffractometer using graphite-monochromated Mo K $\alpha$ radiation. A total of 2205 reflections were collected with use of the $\omega-2 \theta$ scanning technique between 2.0 and $49.9^{\circ}$ in $2 \theta$. A total of 1553 reflections with $I>2 \sigma(I)$ were used in the full-matrix least-squares refinement. The structure was solved by using heavy-atom methods with the NRCC computing package. The final values of the agreement indices were $R$ $=0.062, R_{w}=0.060$, and $\mathrm{GOF}=2.20$.

(10) Conole, G.; Henrick, K.; McPartlin, M.; Horton, A. D.; Mays, M. J.; Sappa, E. J. Chem. Soc., Dalton Trans. 1990, 2367.

(11) (a) Fontana, S.; Orama, O.; Fischer, E. O.; Schubert, U.; Kreissl, F. R. J. Organomet. Chem. 1978, 149, C57. (b) Ginley, D. S.; Wrighton, M. S. J. Am. Chem. Soc. 1975, 97, 4908 .

(12) Yellow crystals of $\mathbf{5}$ were grown by slow diffusion of $n$-hexane into a dichloromethane solution of 5 at $4{ }^{\circ} \mathrm{C}$. Crystal data: space group $P 2_{1}$ / $c, a=8.681(3) \AA, b=13.420(5) \AA, c=17.630(9) \AA, \beta=103.48(4)^{\circ}$, $Z=4$. X-ray data were collected at room temperature on an EnrafNonius CAD4 diffractometer using graphite-monochromated Mo $\mathrm{K} \alpha$ radiation. A total of 3514 reflections were collected with use of the $\omega-2 \theta$ scanning technique between 2.0 and $49.9^{\circ}$ in $2 \theta$. A total of 2408 reflections with $I>2 \sigma(I)$ were used in the full-matrix least-squares refinement. The structure was solved by using heavy-atom methods with the NRCC computing package. The final values of the agreement indices were $R=0.044, R_{\mathrm{w}}=0.032$, and $\mathrm{GOF}=2.43$. 
Scheme I

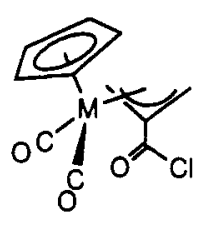

1a, $M=W$

1b, $M=M_{0}$

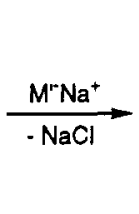

$$
\begin{aligned}
& 2 b, M=M o ; M^{\prime}=C p(C O)_{3} W \\
& 2 c, M=W ; M^{\prime}=C p(C O)_{2} \mathrm{Fe} \\
& 2 d, M=W ; M^{\prime}=(C O)_{5} R e
\end{aligned}
$$

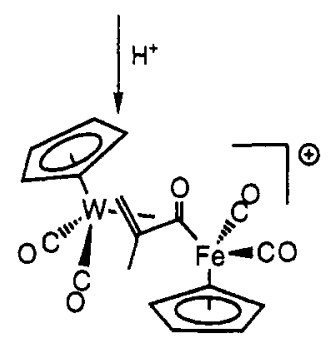

5 endolexo

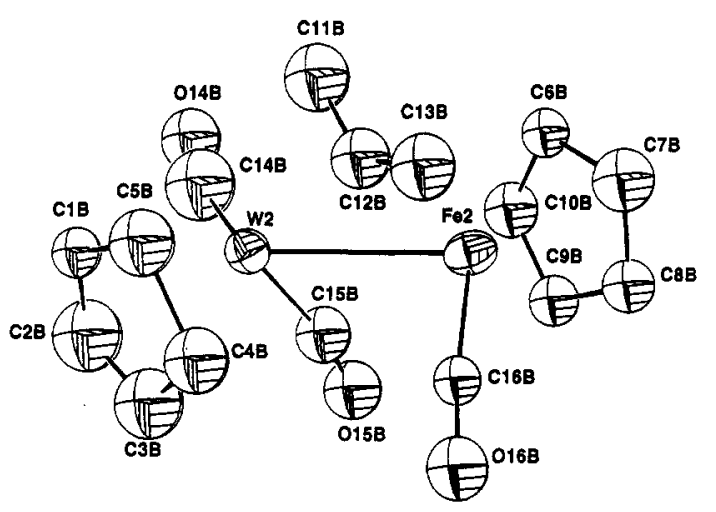

Figure 1. ORTEP drawing of $\mathrm{Cp}(\mathrm{CO})_{2} \mathrm{~W}\left(\mu-\eta^{2}, \eta^{2} \cdot \mathrm{CH}_{2}=\mathrm{C}=\right.$ $\left.\mathrm{CH}_{2}\right) \mathrm{Fe}(\mathrm{CO}) \mathrm{Cp}(4 \mathrm{c})$ with thermal ellipsoids shown at the $50 \%$ probability level. Selected bond distances $(\AA)$ and bond angles (deg) are as follows: $\mathrm{Fe}-\mathrm{C}(12 \mathrm{~B}), 1.91(4) ; \mathrm{Fe}-\mathrm{C}(13 \mathrm{~B}), 2.08(5) ; \mathrm{W}-\mathrm{C}(11 \mathrm{~B}), 2.34(4)$; $\mathrm{W}-\mathrm{C}(12 \mathrm{~B}), 2.07(4) ; \mathrm{C}(12 \mathrm{~B})-\mathrm{C}(13 \mathrm{~B}), 1.34(6) ; \mathrm{C}(11 \mathrm{~B})-\mathrm{C}(12 \mathrm{~B}), 1.45(6)$; $C(11 B)-C(12 B)-C(13 B), 140(4)$.

Treatment of $2 \mathrm{c}$ with $\mathrm{HBF}_{4}$ resulted in the formation of a cationic enone complex $\left[\mathrm{Cp}(\mathrm{CO})_{2} \mathrm{~W}\left(\mu-\eta^{4}, \eta^{1}-\mathrm{CH}_{2}=\mathrm{C}\left(\mathrm{CH}_{3}\right) \mathrm{CO}\right)\right.$ $\mathrm{Fe}(\mathrm{CO})_{2} \mathrm{Cp}_{\mathrm{BBF}}(5){ }^{8}{ }^{8}$ Complex 5 in solution gave a mixture of endo/exo isomers with a ratio of 6.4:1. The structure of 5 was also confirmed by X-ray diffraction analysis. ${ }^{12}$ As shown in Figure 2 , the enone group adopts an s-cis configuration and is in an endo conformation with respect to the $\mathrm{Cp}$ group. ${ }^{13}$ The $\eta^{4}$-coordination of the enone group is revealed by the one $\mathrm{W}-\mathrm{O}$ and three $\mathrm{W}-\mathrm{C}$ bonding distances. A slightly longer $\mathrm{W}-\mathrm{C}(2)$ separation of $2.49(1) \AA$ as compared to the other W-C separations (2.24(1) and $2.28(1) \AA$ ) may be attributed to the steric effect of the iron moiety and to a relatively short $\mathrm{W}-\mathrm{O}(3)$ distance of $2.141(7) \AA$. For a cationic molybdenum butadiene complex, ${ }^{14}$ four isomers (endo/exo and cis/trans) have been observed at low temperature.

(13) (a) Takats, J.; Kurczynski, L. J. Am. Chem. Soc. 1974, 96, 932. (b) Takats, J.; Kurczynski, L. Inorg. Chem. 1976, 15, 3140. (c) Dorf, U. Engel, K.; Erker, G. Organometallics 1983, 2, 462. (d) Tachikawa, M.; Shapley, J. R.; Haltiwanger, R.; Pierpont, C. G. J. Am. Chem. Soc. 1976, 98,4651 . (e) Vong, W. J.; Peng, S. M.; Liu, R. S. Organometallics $1990,9,2187$

(14) Faller, J. M.; Rosan, A. M. J. Am. Chem. Soc. 1977, 99, 4858.
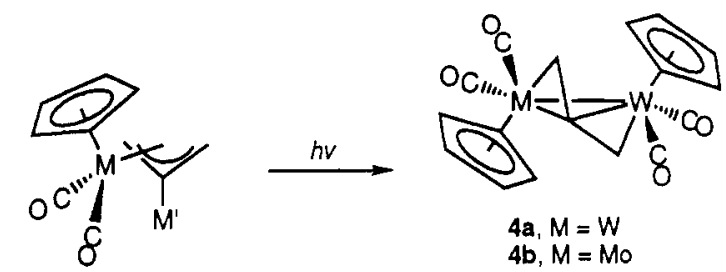

$3 a, M=W ; M^{\prime}=C p(C O)_{3} W$ $3 b, M=M o ; M^{\prime}=C p(C O)_{3} W$

3d, $M=W ; M^{\prime}=(C O)_{5} R e$

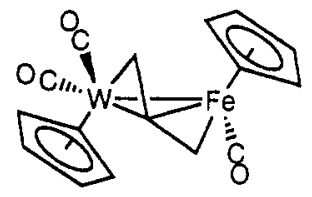

$4 c$

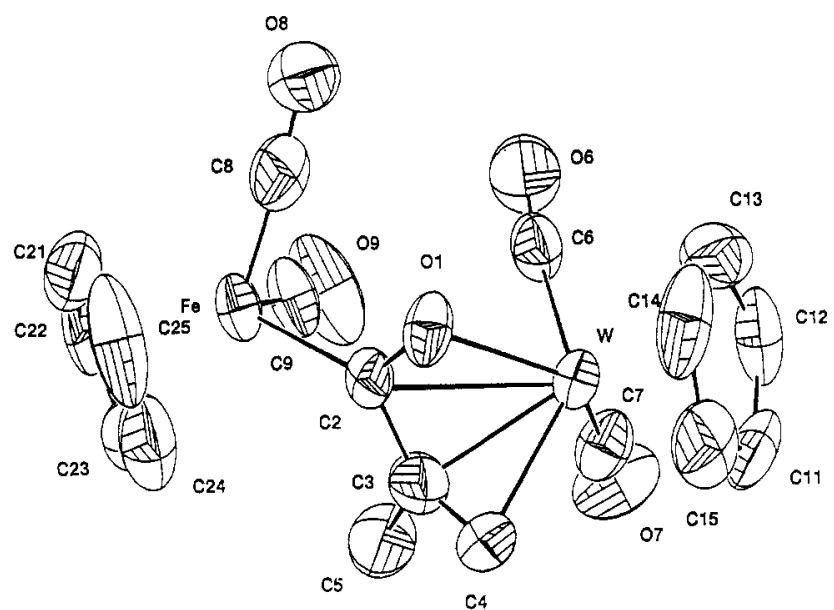

Figure 2. ORTEP drawing of $\mathrm{Cp}(\mathrm{CO})_{2} \mathrm{~W}\left(\mu-\eta^{4}, \eta^{1}-\mathrm{CH}_{2}=\mathrm{C}\left(\mathrm{CH}_{3}\right)\right.$ $\mathrm{CH}=\mathrm{O}) \mathrm{Fe}(\mathrm{CO})_{2} \mathrm{Cp}(5)$ with thermal ellipsoids shown at the $50 \%$ probability level. Selected bond distances $(\AA)$ and bond angles (deg) are as follows: $\mathrm{Fe}-\mathrm{C}(2), 1.946(1) ; \mathrm{W}-\mathrm{O}(1), 2.141(7) ; \mathrm{W}-\mathrm{C}(2), 2.49(1)$; $\mathrm{W}-\mathrm{C}(3), 2.28(1)$; W-C(4), 2.24(1); C(2)-O(1), 1.32(1); C(2)-C(3), 1.43(2); C(3)-C(4), 1.42(2); C(3)-C(5), 1.49(2); C(2)-C(3)-C(4), $115(1) ; \mathrm{O}(1)-\mathrm{C}(2)-\mathrm{C}(3), 110.7(9) ; \mathrm{C}(4)-\mathrm{C}(3)-\mathrm{C}(5), 121(1)$.

In our case, the s-trans configuration was not observed probably due to the steric bulk of the metal moiety.

Using $\beta$-(chlorocarbonyl)allylic metal complexes as starting materials, we have demonstrated the preparation of a heteronuclear complex with a $\beta$-(carbonyl)allylic bridging ligand. Photolysis of this product led efficiently to the heteronuclear $\mu-\eta^{2}, \eta^{2}$-allene complex. Reactivity of allene complexes with heteronuclear metal centers is currently under investigation.

Acknowledgment. We are grateful for financial support of this work by the National Science Council of the Republic of China.

Supplementary Material Available: A textual presentation of the syntheses and spectroscopic data for $2 a, 2 b, 2 c, 2 d, 3 b, 4 b, 4 c$, and 5 and tables of X-ray crystallographic data, positional parameters, anisotropic thermal parameters, and selected bond distances and angles for $4 \mathrm{c}$ and 5 (11 pages). Ordering information is given on any current masthead page. 